\title{
PROFIL DNA GEN FOLLICLE STIMULATING HORMONE RESEPTOR (FSHR) PADA WANITA AKNE DENGAN TEKNIK PCR DAN SEKUENSING DNA
}

\section{DNA PROFILE OF FOLLICLE STIMULATING HORMONE RECEPTOR (FSHR) GENE IN WOMEN ACNE BY USING PCR TECHNIQUE AND DNA SEQUENCING}

\author{
Sjafaraenan, Handayani Lolodatu, Eva Johannes, Rosana Agus dan Arfan Sabran \\ Departemen Biologi, Fakultas Matematika dan Ilmu Pengetahuan alam \\ Universitas Hasanuddin, Makassar \\ enan.gidinnur@gmail.com
}

\begin{abstract}
Abstrak
Penelitian tentang Profil DNA Gen Follicle Stimulating Hormone reseptor (FSHr) pada Wanita Akne dengan Teknik PCR dan Sekuensing DNA. Penelitian ini bertujuan untuk mengetahui profil DNA Gen Follicle Stimulating Hormone reseptor (FSHr) pada Wanita Akne dengan Teknik PCR dan Sekuensing DNA. Penelitian ini dilakukan pada bulan Februari-April 2016. Metode penelitian ini adalah observasional dengan rancangan penelitian cross sectional, teknik laboratorium dilakukan sesuai dengan prosedur PCR dan Sekuensing DNA. Pengambilan sampel dilakukan di Instalasi Laboratorium RS. Labuang Baji Makassar dan Analisis sampel dilakukan di Laboratorium Genetika dan Laboratorium Terpadu Gedung SCIENCE BUILDING Fakultas Matematika dan IImu Pengetahuan Alam, Universitas Hasanuddin, Makassar, Sulawesi Selatan. Pengambilan serum darah melalui vena mediana kubiti dilakukan pada 10 responden wanita penderita akne, yang bersedia menjadi responden dan telah memenuhi kriteria inklusi. Hasil penelitian menunjukkan, bahwa setiap responden memiliki gen FSHr, 4 sampel yang di sekuensing memiliki genotipe Asn385Asn, Asn385Ser, dan Ser385Ser. Kesimpulan dari penelitian diketahui bahwa Profil DNA Gen Follicle Stimulating Hormone reseptor (FSHr) pada wanita akne yaitu Asn385Asn, Asn385Ser, dan Ser385Ser dimana polimorfisme yang terjadi pada Gen FSHr dapat menyebabkan terjadinya gangguan signal tranduksi pada sel granulosa ovarium.
\end{abstract}

Kata kunci : Gen FSHr, Akne, PCR, Sekuensing DNA

\section{Abstract}

The research about DNA profile of Follicle Stimulating Hormone receptor (FSHr) gene in women acne by using PCR technique and DNA Sequencing. The purpose of this research is to find out the DNA profile of Follicle Stimulating Hormone receptor (FSHr) in women acne by using PCR technique and DNA Sequencing. This research was held in February to April 2016. The method of this research is observational with cross sectional research design, laboratory technique conducted according to PCR procedure and DNA Sequencing. The sample collection was held in Laboratory Installation of RS. Labuang Baji Makassar and the sample analysis do in the Genetics Laboratory and Integrated Laboratory of Science Building of MIPA Faculty, University of Hasanuddin, Makassar, South Sulawesi. The collecting of blood serum through mediana kubiti veins performed on 10 women respondents who suffered of acne, who willing to be respondent and has been comply the inclusive criteria. The result of the research shows that each of respondent has FSHr gene, 4 samples were sequenced have Asn385Asn, Asn385Ser, and Ser385Ser genotype. The conclusion of the research, it is know if DNA profile of Follicle Stimulating Hormone receptor (FSHr) gene in women acne are Asn385Asn, Asn385Ser, and Ser385Ser, where polymorphisms that happen to FSHr gene can cause disruption of tranduction signal in granulosa ovarian cell.

Keyword : FSHr gene, acne, PCR, DNA sequencing 


\section{Pendahuluan}

Akne vulgaris adalah salah satu penyakit yang menjadi masalah bagi remaja dan dewasa muda. Penyakit ini tidak fatal, tetapi cukup merisaukan karena mengurangi kepercayaan diri dan dapat meningkatkan insiden kecemasan sampai depresi. Insiden jerawat $80-100 \%$ pada usia dewasa muda, yaitu umur 14-17 tahun pada wanita, 16-19 tahun pada pria (Yuindartanto, 2009).

Etiologi pasti dari penyakit akne belum diketahui secara pasti, namun diduga bahwa akne merupakan penyakit faktoral yang manifestasi klinisnya dipengaruhi dari beberapa faktor seperti hormon, genetik, kosmetik, makanan, trauma, lingkungan fisik, setress psikis (Hendarta dan Rahma, 2003).

Aktivitas kelenjar sebasea yang meningkat dipengaruhi oleh hormon androgen, tetapi pada wanita hormon androgen tidak meningkat pada sekitar periode menstruasi. Penjelasan untuk peningkatan aktivitas kelenjar sebasea sekitar periode menstruasi mungkin tidak berhubungan dengan kadar hormon androgen pada wanita tetapi lebih berhubungan dengan kadar hormone estrogen yang sangat rendah tepat sebelum dan selama periode menstruasi. Hal ini menyebabkan pada periode menstruasi perempuan lebih banyak menderita akne vulgaris maupun eksaserbasinya.

Folikel Stimulating Hormon (FSH) adalah hormon utama yang berperan dalam pematangan sel folikel pada ovarium untuk pembentukan sel Ovum. Selain itu, FSH juga bertanggung jawab terhadap pengaturan perkembangan sel germinal pada kedua jenis kelamin dan sintesis hormone estrogen ovarium wanita (Ferlin A. et al, 2008). FSH bekerja dalam sel melalui reseptor khusus, yaitu FSHr yang terletak secara ekslusif pada gonad. Ekspresis FSHr pada manusia dan beberapa mamalia lainnya yang sudah teridentifikasi hanya terdapat pada testis dan ovarium. Pada testis, ekspresi FSHr ekslusif hanya ditemukan pada sel-sel Sertoli, sedangkan pada ovarium FSHR hanya diekspresikan pada sel-sel granulosa (Simoni et al., 1997).

Bagian intraseluler dari FSHR membentuk ikatan dengan protein G yang setelah adanya aktivasi reseptor oleh interaksi hormonal dengan domain ekstraseluler menginisiasi rangkaian peristiwa yang terutama menyebabkan efek biologi spesifik dari gonadotropin. Pembentukan reseptor akan meningkat dengan pesat. Setiap gangguan dalam mekanisme pembentukan reseptor ini akan dapat mempengaruhi kualitas fase luteal suatu daur.

Penelitian ini bertujuan untuk mengetahui Profil DNA Gen Follicle Stimulating Hormone reseptor (FSHr) Pada Penderita Akne Dengan Teknik PCR Dan Sekuensing DNA.

\section{Metode Penelitian}

Rancangan penelitian ini dilakukan dengan rancangan cross sectional. Teknik Laboratorium dikerjakan sesuai dengan prosedur PCR dan Sekuensing DNA.

Pengambilan sampel dilakukan di Instalasi Laboratorium RS. Labuang Baji Makassar dan Analisis sampel dilakukan di Laboratorium Genetika dan Laboratorium Terpadu Gedung SCIENCE BUILDING Fakultas Matematika dan Ilmu Pengetahuan Alam, Universitas Hasanuddin, Makassar, Sulawesi Selatan.

\section{Pengambilan Darah}

Pengambilan serum darah melalui vena mediana kubiti dilakukan pada 10 responden wanita penderita akne, sampel dalam penelitian ini adalah wanita yang berumur 20-25 tahun. 
Pengambilan sampel darah melalui vena mediana kubiti sebanyak $2 \mathrm{~mL}$ dengan menggunakan spoit. Sebelum pengambilan darah dilakukan tindakan aseptis dengan mengoleskan alkohol $70 \%$. Setelah itu darah yang diambil dimasukkan ke dalam tabung reaksi (BD Vacultainer K2 EDTA 5,4 mg REF 367856).

\section{Pemeriksaan FSH Reseptor Ekstraksi DNA}

Ekstraksi DNA genom dilakukan dengan mengikuti protocol ekstraksi DNA yang terdapat dalam Geneaid Presto ${ }^{\text {TM }}$ Mini gDNA Blood Kit. Langkah pertama dilakukan preparasi sampel, untuk sampel darah yang diambil dari freezer dipanaskan dalam waterbath dengan suhu $60^{\circ} \mathrm{C}$ selama 1 menit. Sebanyak $300 \mu \mathrm{L}$ sampel darah pada tabung EDTA dipindahkan ke 1,5 $\mathrm{mL}$ tube mikrosentrifuge steril yang diberi tanda 1, 2, 3, 4, 5, 6, 7, 8, 9, 10. Ditambahkan 100mL RBC Buffer, sampel diinkubasi pada suhu ruangan selama 10 menit, lalu disentrifuge selama 5 menit dengan kecepatan 3000xg dan buang supernatan. Tambahkan 200 $\mu \mathrm{L}$ GB Buffer, diinkubasi pada suhu $60^{\circ} \mathrm{C}$ selama 10 menit sampai sampel terlysis, selama inkubasi tiap 3 menit dilakukan pembalikan.

Pada tahap lysis sel, pertama-tama Elution Buffer dipanaskan pada suhu $60^{\circ} \mathrm{C}$. Ditambahkan $200 \mu \mathrm{L}$ larutan Etanol Absolute vorteks selama 10 detik. Setelah itu, pindahkan GD Column disentrifuge dengan kecepatan 13.000 xg selama 2 menit, ganti colect tube dengan yang baru. Pada tahap DNA Binding, ditambahkan 400 $\mu \mathrm{L}$ W1 Buffer ke GD Column disentrifuge selama 30 detik 14.000-16.000 xg cairan dibuang pada colect tube, kemudian tempatkan kembali ke GD Column.

Selanjutnya tahap pencucian (Wash), ditambahkan 600 $\mu \mathrm{L}$ Wash Buffer yang telah dicampur etanol, disentrifuge selama 30 sampai 60 detik pada 14.000-16.000 xg cairan dibuang pada colect tube dan tempatka ke GD Column, lalu disentrifuge selama 3 menit untuk mengeringkan matriks column. Pada tahap DNA Elution, dimasukkan larutan Elution Buffer ke dalam tabung effendorf. Kemudian, GD Column ditempatkan diatas tabung mikrosentrifuge dipanaskan sebelumnya tepat di bagian tengah matriks, lalu dibiarkan selama 3 menit, disentrifuge selama 30 detik untuk mengelusi DNA murni. DNA yang murni lalu disimpan di storage (pendingin). Dilakukan visualisasi Uji Ekstraksi DNA dengan Elektroforesis.

\section{Pembuatan PCR Mix}

Diambil masing-masing 10uL Primer FSHR Forward dan reverse dan dimasukkan kedalam tabung effendorf steril, Forward : 5' TTT GTG GTC ATC TGT GGC TGC 3', Reverse : 5' TCA AAG GCA AGA CTG AAT TAT CAT 3' (Livshyts et al, 2009). Kemudian sebanyak 100 uL GoTaq MasterMix Green dimasukkan kedalam tabung effendorf steril dan dicampurkan dengan primer serta ditambahkan $\mathrm{H}_{2} \mathrm{O}$ sebanyak $90 \mu \mathrm{L}$. Selanjutnya sebanyak 20uL Mix Primer dan GoTaq Mastermix dimasukkan kedalam tabung PCR lalu ditambahkan DNA 5 uL pada masing-masing tabung PCR.

\section{Deteksi Amplifikasi DNA dengan metode PCR}

Tabung PCR yang berisi PCR Mix dan DNA dimasukkan kedalam mesin Thermal Cycler Veriti Aplied Biosystem. Setelah itu mesin Thermal Cyler dijalankan dengan kondisi PCR : Predenaturasi $95^{\circ} \mathrm{C}$ selama 2 menit sebanyak 1 siklus, Denaturasi $94^{\circ} \mathrm{C}$ selama 1 menit, Annealing $58^{\circ} \mathrm{C}$ selama 45 detik, Extension $72^{\circ} \mathrm{C}$ selama 45 detik, post extensi $72^{\circ} \mathrm{C}$ selama 5 menit sebanyak 34 siklus.Selanjutnya hasil PCR gen FSHR dielektroforesis untuk melihat band hasil amplifikasi. 


\section{Deteksi Produk PCR dengan Elektroforesis Elektroforesis}

Gel Agarosa 2\% yang telah dibuat kedalam dimasukkan ke dalam elenmeyer yang telah berisi TAE buffer 0,5x sebanyak $100 \mathrm{ml}$, kemudian dipanaskan ke dalam microwave selama 2 menit hingga mendidih, lalu ditambahkan $8 \mu \mathrm{L}$ Ethidium Bromida. Cairan gel lalu didinginkan pada suhu kamar. Setelah agak dingin, caran gel dituang ke cetakan gel elektorforesis dengan menggunakan sisir gel dengan jumlah sisir 17 sumur. Diambil 2 uL loading dye dan dicampurkan ke dalam 5 uL PCR produk setiap sampel, selanjutnya dimasukkan kedalam sumur yang ada pada gel agarose. Diambil 5 ul ladder 100 bp dan dimasukkan dalam sumur paling ujung dari gel agarose. Selanjutnya power suply dinyalakan dengan pengaturan 100 volt selama 50 menit. Setelah 50 menit elektroforesis dihentikan dan gel agarose diangkat untuk diamati dibawah sinar UV dan dimasukkan dalam Gel Documentation untuk melihat band hasil amplifikasi gen FSHR sebesar 520 bp. Hasil positif jika terdapat pita DNA yang sejajar dengan marker 520bp dan negative jika tidak terdpat pita pada gel.

\section{Sekuensing DNA}

Produk PCR dari sampel menunjukkan hasil elektroforesis yang positif dilakukan sekuensing DNA oleh $1^{\text {st }}$ Base melalui PT. Genetika Science Indonesia. Proses sekuensing DNA dilakukan menggunakan metode Sanger dideoksi. Selanjutnya dilakukan analisis hasil sekuensing dengan melakukan BLAST urutan nukleotida dari hasil sekuensing dengan data base yang tersedia pada situs www.ncbi.nlm.nih.gov yang digunakan untuk mencari similaritas suatu sekuen nukleotida atau protein (query sequence) dengan sekuens data base (subject sequence). Pensejajaran sekuens dilakukan menggunakan Program Clustal W.

\section{Hasil dan Pembahasan}

\section{Hasil}

Penelitian ini menganalisis Pofil DNA Gen Follicle Stimulating Hormone reseptor pada wanita akne, dengan 10 jumlah sampel darah, yang diperoleh dari mahasiswa Jurusan Biologi, Fakultas Matematika dan IImu Pengetahuan Alam, Universitas Hasanuddin.

\subsection{Ekstraksi DNA}

Proses ekstraksi DNA dilakukan untuk memisahkan genom DNA dari molekul lain di dalam suatu sel. Langkah awal dalam analisis DNA adalah memisahkan genom DNA menjadi fragmen-fragmen spesifik yang lebih kecil yaitu dengan cara mengekstraksi genom DNA dari darah.

Ekstraksi dilakukan berdasarkan protocol Geneaid Fresfo ${ }^{T M}$ Gdna Blood Kit. Dimana pada Ekstraksi DNA yang dilakukan terdapat beberapa tahap yaitu, Tahap Preparasi Sampel, Tahap Lisis sel, Tahap Pengikatan DNA, Tahap Pencucian, Tahap Pemisahan DNA dari senyawasenyawa kimia sehingga mendapakatkan DNA murni. Pada tahap preparasi sampel ditambahkan RBC Buffer dan GB Buffer untuk memisahkan atau memecahkan leukosit dalam sampel untuk mempermudah proses lisis sel selanjutnya, suhu yang tinggi akan membantu mempercepat terjadinya lisis sel.

Selanjutnya, dilakukan penambahan Etanol Absolut untuk mengumpulkan DNA, proses ini biasa disebut juga DNA binding karena pada tahapan ini sampel DNA dikumpulkan. Pada tahap 
ini konsentrasi etanol yang tinggi tidak akan merusak DNA, melainkan dengan semakin tinggi konsentrasi etanol yang digunakan maka semakin kuat etanol me ngumpulkam DNA. DNA yang diperoleh dipindahkan ke dalam GD Column, matriks pada GD column akan mengikat DNA sementara kontaminan akan tersuspensi. Pada tahap ini dilakukan pencucian dengan menggunakan Wash Buffer, Wash Buffer akan menghilangkan kontaminan sedangkan DNA tetap terikat pada matriks.

Pada tahapan selanjutnya, dilakukan proses rehidrasi DNA yang bertujuan untuk mencairkan atau melepaskan DNA, karena produk DNA dalam bentuk sedimen. Rehidrasi dilakukan dengan menambahkan larutan pre-heated Elution Buffer yang dapat melarutkan DNA. Setelah proses rehidrasi selesai maka produk DNA yang selanjutnya akan divisualisasi pada elektroforesis. Hasil visualisasi ektraksi DNA dengan elektroforesis disajikan dalam bentuk gambar sebagai berikut :

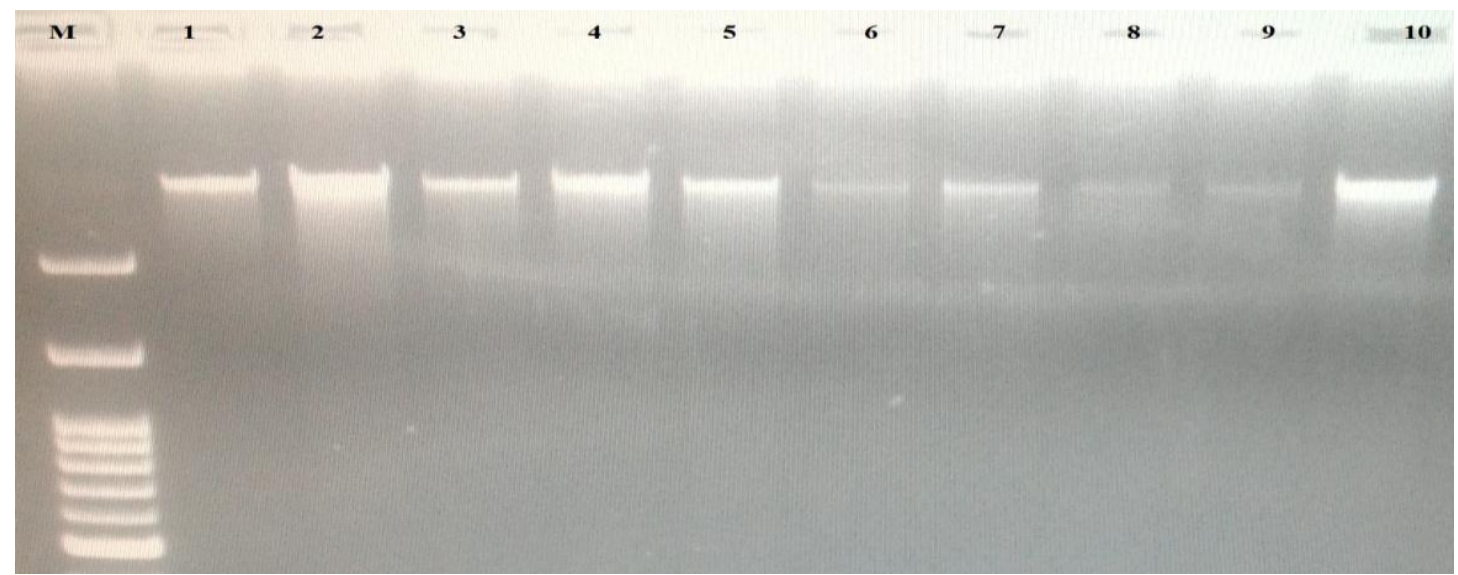

Gambar 1 : Visualisasi Ekstraksi DNA Gen FSH reseptor

Keterangan :

M : Marker

1-10 : Urutan Sampel

Dari hasil visualisasi elektroforesis pada gambar 1, terlihat 10 sampel yang diuji menunjukkan bahwa semua sampel memiliki gen FSH reseptor, kualitas DNA dari ekstraksi dengan menggunakan protokol Geneaid Fresfo ${ }^{\text {TM }}$ Gdna Blood Kit bagus.

\subsection{Amplifikasi dengan Metode Polymerase Chain Reaction (PCR)}

Polymerase Chain Reaction (PCR) adalah suatu teknik sintesis dan amplifikasi DNA secara in vitro (Handoyo dan Ari, 2000). PCR mampu menghasilkan sejumlah besar fragmen DNA spesifik dengan panjang dan sekuens yang telah ditentukan dari sejumlah kecil template (Nasir, 2002). Primer yang digunakan adalah FSHR Forward : 5' TTT GTG GTC ATC TGT GGC TGC 3', Reverse : 5' TCA AAG GCA AGA CTG AAT TAT CAT 3' (Livshyts et al, 2009).

Primer ini dikhususkan pada gen FSHR. Sebelum dilakukan Amplifikasi DNA terlebih dahulu dilakukan prosedur PCR mix. Dengan menggunakan 2 primer spesifik yang akan berikatan pada ujung 5' masing-masing sisi DNA maka dihasilkan amplifikasi gen FSH reseptor sepanjang 520 bp. Seteleh proses amplifikasi selanjutnya akan dilakukan proses elektroforesis menggunakan Agarose $2 \%$ untuk melihat pendaran DNA hasil amplifikasi PCR sehingga diperoleh band dengan ukuran 520 pasangan basa (bp). Hasil amplifikasi DNA dengan teknik PCR disajikan dalam bentuk gambar sebagai berikut : 


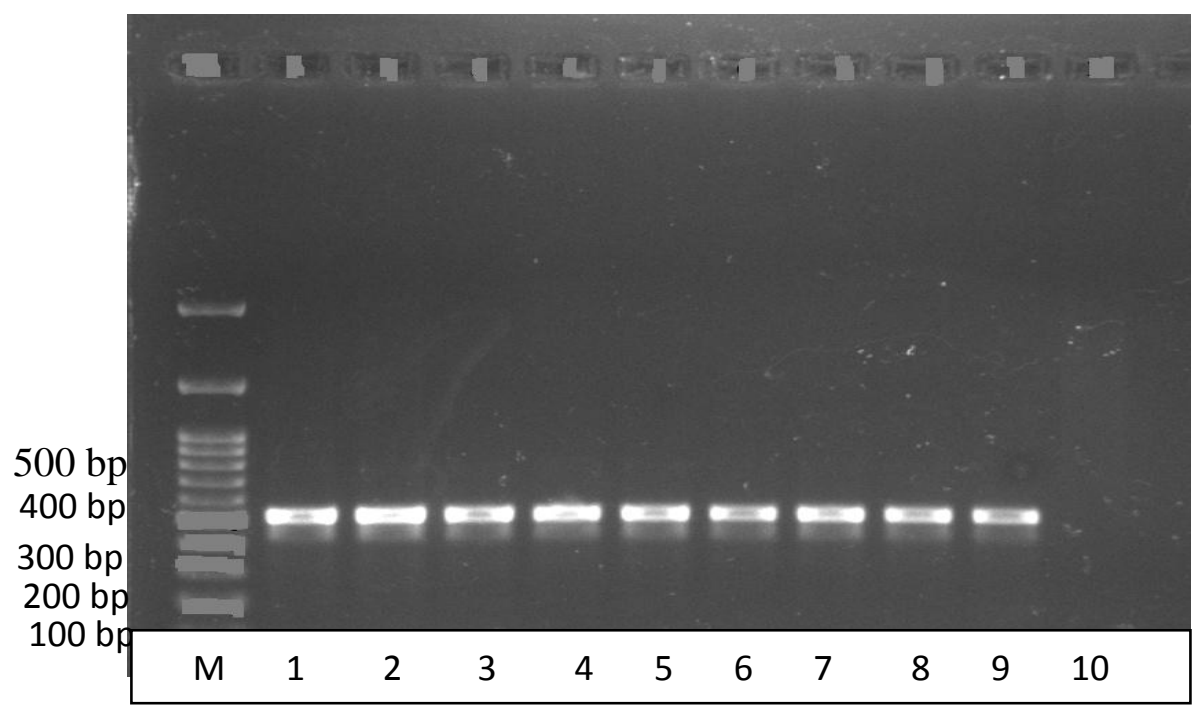

Gambar 2. Hasil Elektroforesis dari PCR untuk Deteksi Gen FSHr

Menurut (Purnami, 2009), keberhasilan amplifikasi DNA dengan PCR ditentukan oleh beberapa faktor yaitu, kemurnian dan konsentrasi komponen dalam larutan premix PCR, primer oligonukleotida gen, jumlah dan kemurnian DNA sampel, faktor teknis dan non-teknis misalnya kontaminasi.

Pada gambar 2 dapat dilihat bahwa pada semua subjek penelitian memiliki gen FSHR dalam selnya, namun untuk melihat adanya perubahan atau mutasi urutan nukleotida subjek maka dilakukan Sekuensing DNA. Ekstraksi DNA dari sampel darah wanita penderita akne yang telah dilakukan dengan hasil 520 bp ini merupakan DNA stok yang akan dipakai untuk amplifikasi PCR dan dilanjutkan ke tahap sekuensing.

\subsection{Hasil Analisis Sekuensing}

Sekuensing merupakan tahap akhir dalam menentukan urutan nukleotida fragmen hasil amplifikasi dengan PCR. Sekuensing dilakukan dengan metode Sanger menggunakan Automatic DNA Sequencer yang berdasarkan pada metode dye terminator labelling. Tahapan sekuensing DNA yang dilakukan pada penelitian ini meliputi : (1) penyiapan DNA, (2) proses amplifikasi melalui PCR dengan menggunakan primer universal, (3) pemurnian DNA, (4) elektroforesis, dan (5) pembacaan elektroforegam hasil sekuensing. Data yang diperoleh berupa elektroforegram dalam bentuk $A B I$ file, dimana setiap nukleoida ditunjukkan oleh warna yang berbeda. Nukleotida Adenin (A) ditunjukkan dengan warna hijau, Guanin (G) ditunjukkan dengan warna hitam, Timin (T) ditunjukkan dengan warna merah dan Sitosin (C) ditunjukkan dengan warna biru. Analisis hasil sekuensing produk PCR dilakukan dengan membandingkan urutan nukleotida sampel terhadap urutan nukleotida Kontrol. Urutan nukleotida sampel dan urutan nukleotida kontrol dimasukkan pada program ini yang dengan otomatis program ini akan mengurutkan nukleotida sampel sesuai dengan urutan dan posisi nukleotida standar dan kemudian akan menandai nukleotida tertentu yang berbeda dengan nukleotida kontrol. Adanya mutasi pada daerah Gen Follicle Stimulating Hormone reseptor diketahui dengan membandingkan elektroforegam sampel populasi dengan urutan nukleotida standar rCRS (revised Cambridge Reference Sequence).

Sebanyak 4 sampel dipilih yang terbaik dari 10 sampel untuk di sekuensing sesuai dengan seleksi setelah dilakukan purifikasi atau pemurnian DNA sampel oleh PT. Genetika Science 
Indonesia. Hasil sekuensing mengkode pada urutan kodon 385 dan terjadi perubahan yang ditandai dengan munculnya peak pada satu lengan kromosom mengkode Adenin dan satu lengan kromosom mengkode Guanin. Hasil Sekuensing 4 sampel DNA Gen Follicle Stimulating Hormone reseptor (FSHr) pada wanita akne disajikan dalam bentuk gambar elektroforegam sebagai berikut :

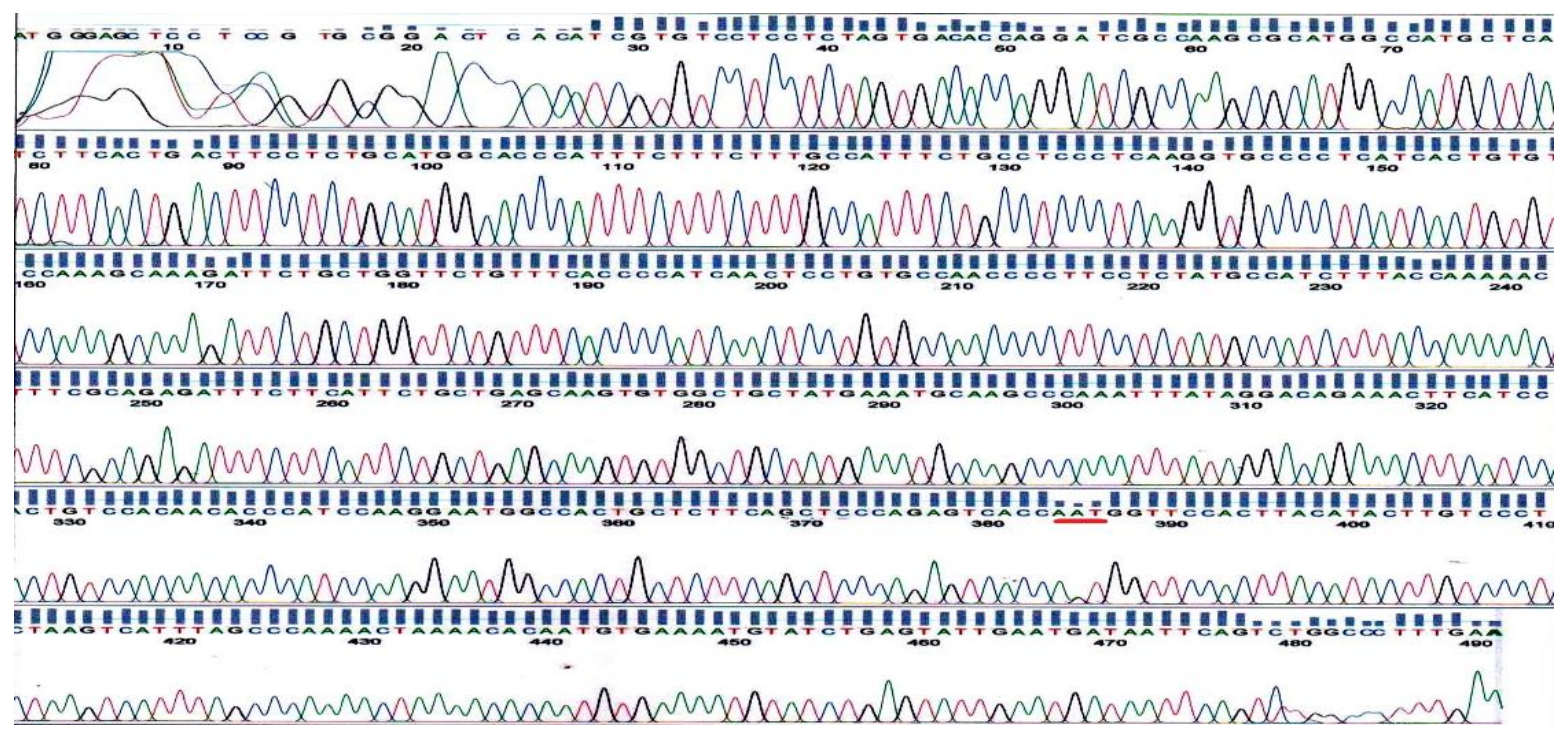

\section{Gambar 3. Hasil Sekeunsing FSH reseptor sampel 1}

Dari hasil sekuensing gambar 3 pada penelitian ini dimana pada sampel 1 tidak terjadi perubahan urutan nukleotida karena sampel 1 merupakan sampel Homozigot yang mengkode Adenin sehingga subjek sampel 1 memiliki genotipe Asn385Asn.

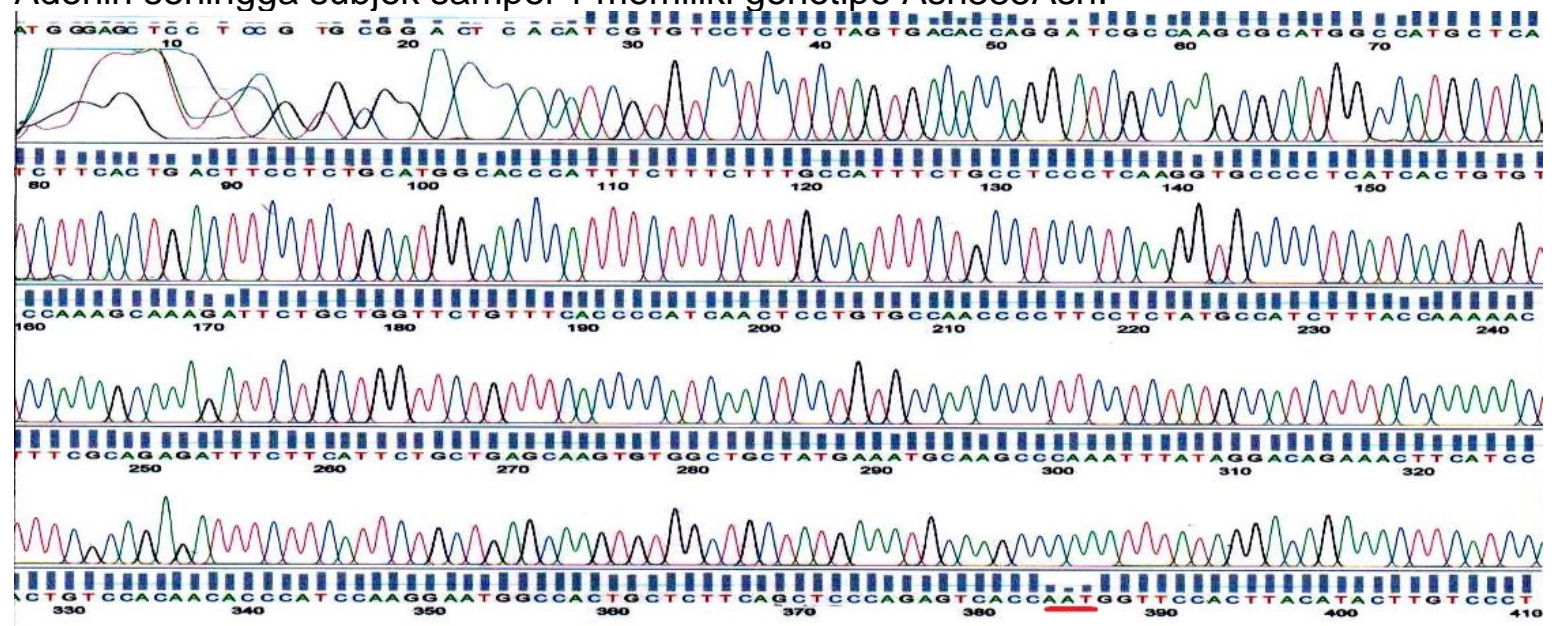

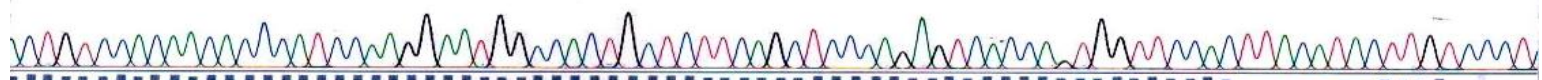

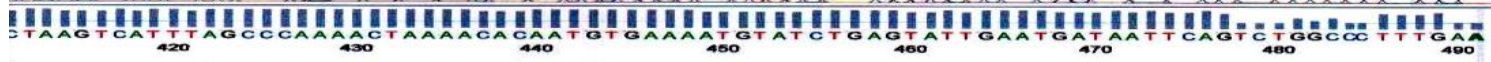

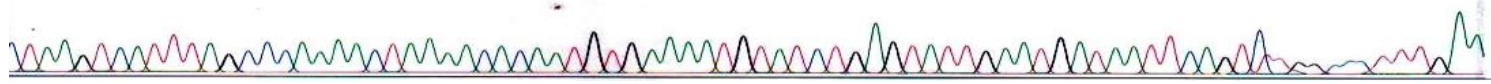
Gambar 4. Hasil Sekuensing FSH reseptor sampel 2 
Pada gambar 4 dapat dilihat bahwa sampel 2 terjadi perubahan dimana munculnya peak yang tumpang tindih karena pada satu lengan kromosom mengkode Adenin dan satu lengan lainnya mengkode Guanin sehingga sampel 2 dikategorikan sebagai subjek Heterozigot yang memiliki genotipe Asn385Ser.

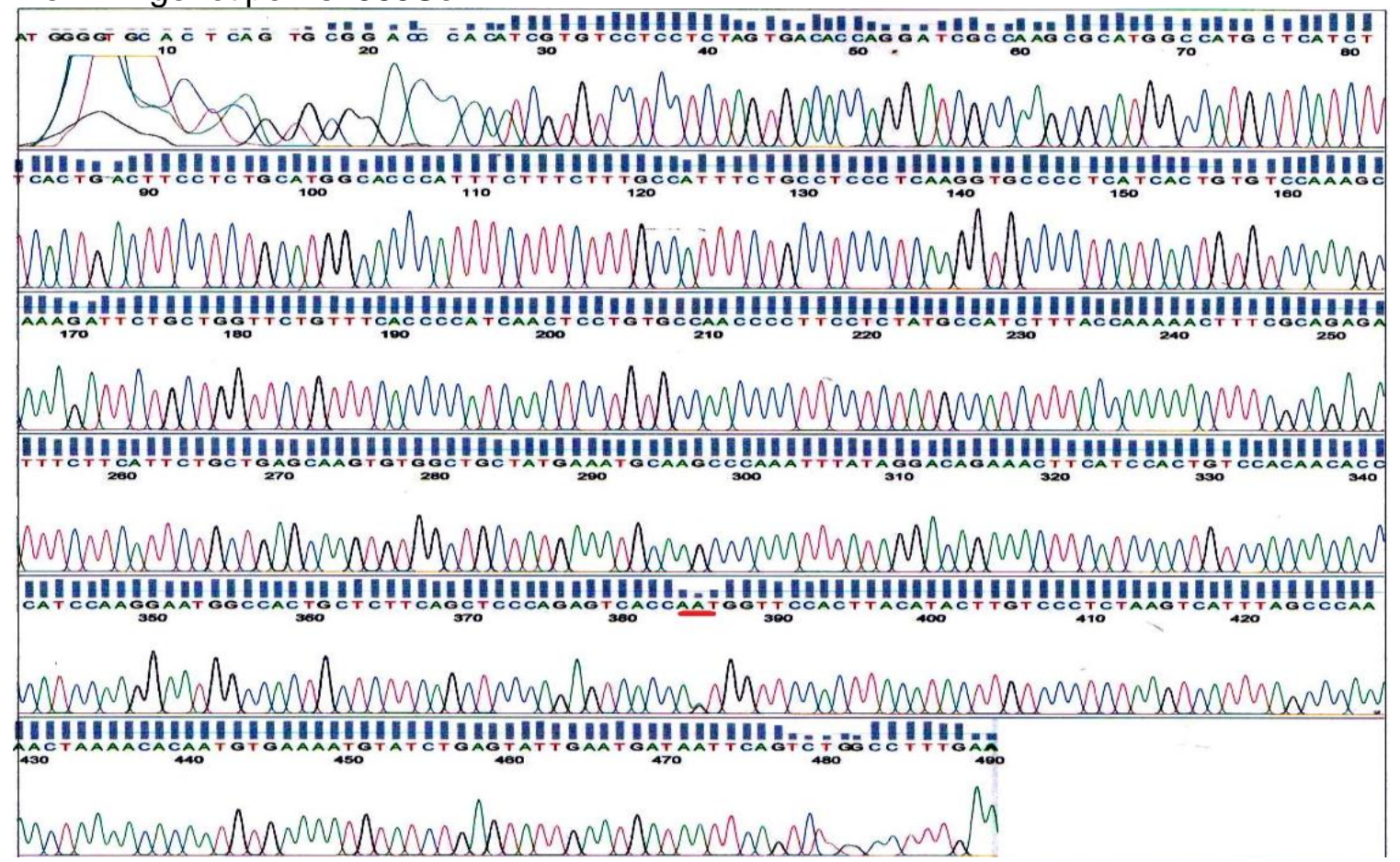

Gambar 5. Hasil Sekuensing FSH reseptor sampel 5

Pada gambar 5 dilihat bahwa Sampel 5 mempunyai kesamaan dengan sampel 2 dalam urutan nukleotidanya sehingga sampel 5 dikategorikan sebagai subjek heterozigot yang memiliki genotipe Asn385Ser. 


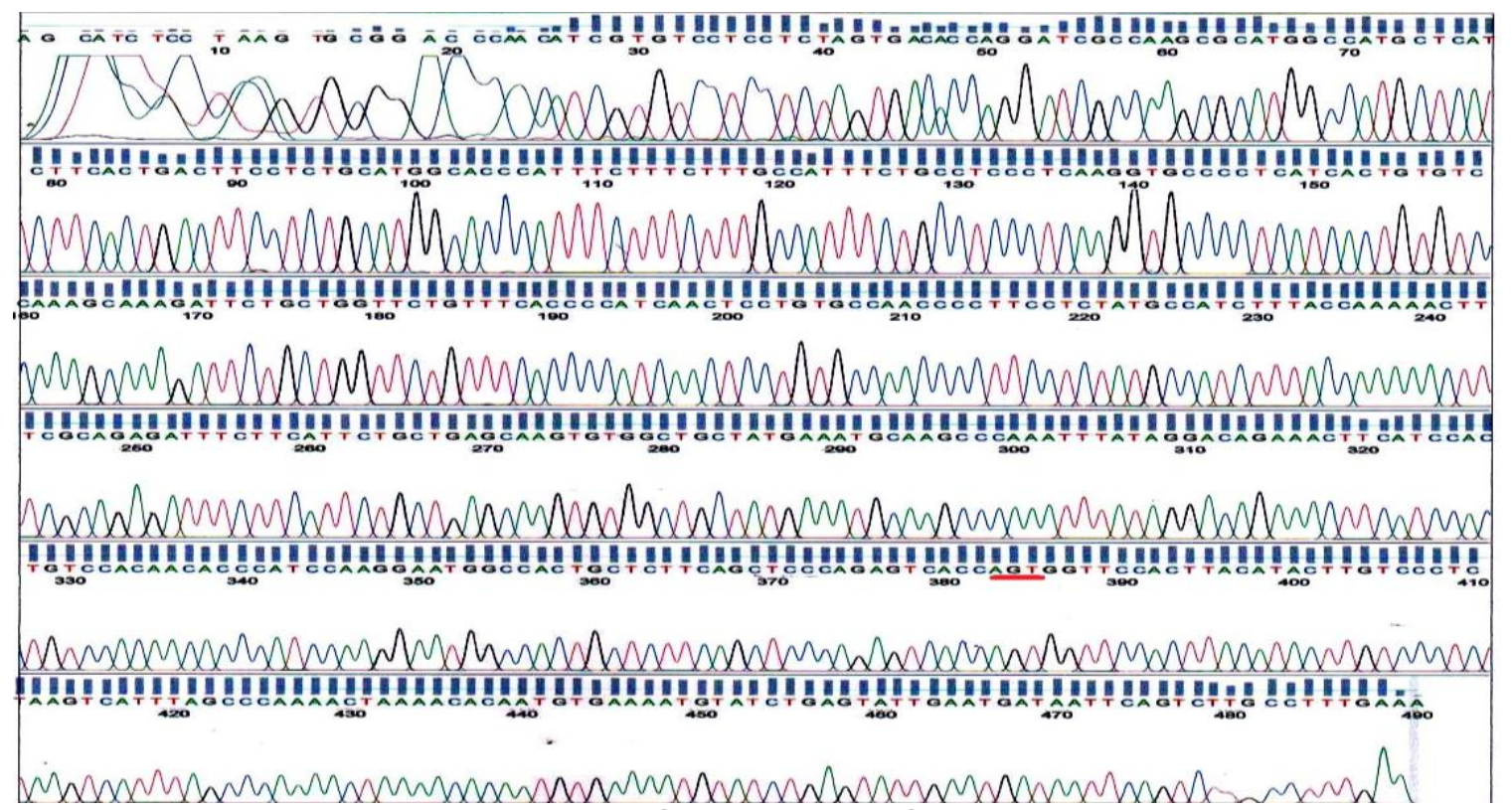

Gambar 6. Hasil Sekuensing FSH reseptor sampel 9

Pada gambar 6 sampel 9 sebagai kontrol merupakan sampel Homozigot yang memiliki peak lengan kromosom Guanin $(G)$ sehingga sampel dikategorikan memiliki genotipe Ser385Ser.

Sampel yang di sekuensing kemudian di BLAST untuk melihat urutan nukleotida dari hasil sekuensing dengan data base yang tersedia pada situs www.ncbi.nlm.nih.gov yang digunakan untuk mencari similaritas suatu sekuen nukleotida atau protein (query sequence) dengan sekuens data base (subject sequence). Pensejajaran sekuens dilakukan menggunakan Program Clustal W. Hasil dari BLAST urutan nukleotida hasil sekuensing dengan data base ncbi 99\% dan 98\% dimana sampel merupakan Gen Follicle Stimulating Hormone reseptor (FSHr).

\section{Pembahasan}

Akne vulgaris biasanya muncul disaat seseorang menginjak umur pubertas. Pada wanita, kejadian akne bisa saja muncul satu tahun lebih dulu dibanding menstruasi pertamanya. Akne vulgaris diduga sebagai penyakit turunan. Selain faktor hormonal dan keturunan di atas, banyak faktor lainnya yang diduga memicu timbulnya akne vulgaris, antara lain makanan/diet dengan kadar lemak tinggi, trauma fisik pada lesi akne, penggunaan kosmetik, timbul stres, dan lainnya (Wasitaatmadja, 2010).

Kriteria inklusi sampel merupakan tahap penting dalam penelitian ini, dimana pengambilan serum darah melalui vena mediana kubiti dilakukan pada 10 responden wanita penderita Akne, sampel dalam penelitian ini adalah wanita yang berumur 20-25 tahun, berumur antara 20-25 tahun, merupakan wanita penderita Akne, tidak mempunyai riwayat penyakit kronis, tidak menderita hipertensi, bersedia menjadi peserta.

Pada beberapa penelitian yang dilakukan sebelumnya mengatakan bahwa setiap gangguan dalam mekanisme pembentukan reseptor FSH akan dapat mempengaruhi kualitas fase luteal suatu daur sehingga menyebabkan beberapa kelainan atau penyakit contohnya penyakit endometris, penuaan, sindrom ovarian.

Gambar 1 menunjukkan bagaimana pola pita DNA sebelum dilakukan Polymerase Chain Reaction, dimana pada semua sampel terbentuk pita tunggal. Pita yang terbentuk dapat dilihat 
dengan jelas pada sampel nomor 1, 2, 3, 4,5, 6, 7, 8, 9 dan 10, dapat dilihat bahwa setiap subjek sampel yang diteliti menandakan bahwa didalam selnya terdapat gen yang mengkode reseptor FSH (Livshyts et al., 2009).

Pada gambar 2 yaitu hasil Amplifikasi DNA menunjukkan pada sampel 10, tidak terbentuk pita tunggal DNA dikarenakan pada sampel ke-10 terdapat DNA yang terekstraksi dalam jumlah yang sedikit. Sebanyak 4 sampel dipilih yang terbaik dari 10 sampel untuk di sekuensing. Hasil sekuensing pada semua sampel akne mengkode pada urutan kodon 385, dimana pada sampel 1 tidak terjadi perubahan nukleotida yang ditandai dengan peak lengan kromosom Adenin (A), pada sampel 2 dan 5 terjadi perubahan yang ditandai dengan munculnya peak yang tumpang tindih dimana pada satu lengan kromosom mengkode Adenin dan satu lengan kromosom mengkode Guanin. Sedangkan pada sampel 9 sebagai kontrol mengkode peak lengan kromosom Guanin (G). Ketika hasil sekuensing semua sampel diubah untuk melihat asam amino yang dihasilkan maka didapatkan data sampel 1 bergenotipe Asn385Asn, sampel 2 dan 5 mempunyai kesamaan dimana memiliki genotipe Asn385Ser dan pada sampel 9 sebagai kontrol memiliki genotipe Ser385Ser.

Jika terjadi perubahan pada basa nitrogen maka akan mempengaruhi pembentukan asam amino, asam amino yang dihasilkam akan mempengaruhi pembentukan protein dan protein akan mempengaruhi enzim yang dihasilkan sehingga akan terjadi kelaian pada sistem tubuh.

Dari hasil sekuensing pada penelitian ini dimana pada sampel 1 ( normal) tidak terjadi mutasi karena sampel 1 merupakan sampel Homozigot yang mengkode Adenin sehingga subjek sampel 1 memiliki genotipe Asn385Asn, pada sampel 2 dimana munculnya peak yang tumpang tindih karena pada satu lengan kromosom mengkode Adenin dan satu lengan lainnya mengkode Guanin sehingga sampel 2 dikategorikan sebagai subjek Heterozigot yang memiliki genotipe Asn385Ser begitu pula dengan sampel 5 merupakan subjek heterozigot yang memiliki genotipe Asn385Ser, sedangkan pada sampel 9 kontrol merupakan sampel Homozigot yang memiliki genotipe Ser385Ser.

Berdasarkan kriteria inklusi subjek dilihat dari tingkat keparahan timbulnya akne sesuai dengan Profil DNA. Dari setiap sampel yang diteliti dan dilihat dari profil hidup subjek semua sampel didapatkan bahwa sebagian besar sampel menderita akne pada saat menstruasi dan pada saat stress saja sedangkan pada sampel 9 tidak pernah menderita akne meskipun pada saat menstruasi dan pada saat stress. Terdapat perbedaan proporsi genotipe yang menarik dan perbedaan ini terutama disebabkan oleh perbedaan etnik subjek yang diamati. Dimana setiap sampel terdapat perbedaan suku ,ras, makanan yang dikonsumsi berbeda satu dengan yang lain sehingga menghasilkan metabolisme berbeda. Dilihat dari tingkat kebersihan wajah pada sampel 9 sebagai kontrol merupakan sampel yang memiliki tingkat kebersihan wajah yang cukup tinggi dari orang normal biasanya, dan tidak pernah menderita Akne meski pada saat menstruasi dan mengalami stress, hal ini dikarenakan sampel 9 bergenotipe Ser385Ser.

Dari hasil penelitian yang dilakukan dapat disimpulkan bahwa genotipe Ser385Ser resisten terhadap estrogen sehingga sampel 9 sebagai kontrol lebih jarang terkena akne. Dimana Serin merupakan asam amino esensial bagi manusia, sebagai penyusun protein non-enzim dimana rantai sampingnya dapat mengalami glikolisasi yang dapat menjelaskan gangguan akibat diabetes. Serina juga merupakan satu dari tiga asam amino yang biasanya terfosforilasi oleh enzim kinase pada saat transduksi signal pada eukariota. Asam amino Asparagin diperlukan oleh sistem saraf untuk menjaga kesetimbangan dan dalam transformasi asam amino serta berperan penting dalam sintesis ammonia. Hasil penelitian yang dilakukan sesuai dengan teori Yuni Ahda, dkk, 2004 yang menyatakan bahwa perbedaan aktivitas promotor akibat polimorfisme pada akhirnya sangat memungkinkan merubah sensitivitas ovarium terhadap $\mathrm{FSH}$, dimana genotipe Asn/Asn dapat menaikkan aktivitas promotor FSH secara bermakna, 
Ser/Ser dapat menurunkan aktivitas promotor FSH secara bermakna sedangkan Asn/Ser tidak mempengaruhi aktivitas promotor secara bermakna.

Berdasarkan hasil penelitian yang dilakukan ini sudah sesuai dengan teori Balkan et al, 2010 yang menyatakan bahwa dampak dari terjadinya polimorfisme Asn-Ser pada gen FSH tidak terlalu memberikan gambaran penurunan kadar FSH plasma, dari penelitian tersebut maka perlu dilakukan penelitian lanjutan yang bertujuan mengukur kadar estrogen dalam serum darah subjek untuk membuktikan bahwa polimorfisme yang terjadi pada gen FSHR dapat menyebabkan terjadinya gangguan signal tranduksi pada sel granulosa ovarium, sehingga menyebabkan menurunnya produksi estrogen pada wanita dan pada akhirnya dalam waktu yang lama dapat menyebabkan gangguan fertilitas.

\section{Kesimpulan}

Berdasarkan hasil penelitian yang dilakukan ini dapat diketahui profil gen DNA Follicle Stimulating Hormone reseptor (FSHr) pada wanita penderita akne dimana pada sampel ditemukan perubahan urutan nukleotida pada urutan kodon 385, sehingga penderita akne memiliki genotipe yaitu Asn385Asn, Asn385Ser, Ser385Ser yang dapat mempengaruhi aktivitas FSH reseptor pada wanita penderita akne.

\section{Daftar Pustaka}

Balkan M., Abdullah G., Hasan A., Ozlem I. and Emin E., 2010. Research Article

Barratt $\mathrm{H}$, Hamilton F, Car J, Lyons C, Layton A, Majeed A. Outcome measures in acne vulgaris: systematic review. British Journal of Dermatology. 160(3):132-6. 2009.

Cuncliffe WJ. 2007. Inflammation in acne scarring: a comparison of the responsesin lesions from patients prone and not prone to scar. British Journal of Dermatology. London. Martin Dunitz Ltd . 150(1):72-81.

Djuanda A . 2007. IImu Penyakit Kulit dan Kelamin Ed.5. Fakultas Kedokteran Universitas Indonesia. Jakarta.

Kabau S. 2012. Hubungan antara Pemakaian Jenis Kosmetik dengan Kejadian Acne vulgaris. Jurnal Media Medika Muda. 43(1) :32-6.

Legiawati L. 2010. Perawatan Kulit pada Akne. Medicinal Jurnal Kedokteran Indonesia. 14(2):17-19.

Livshyts G., Sergey P., Sergey K., Iryana S. And Ludmila L. 2009. A distribution of two SNPs in exon 10 of the FSHR gene among the women with a diminished ovarian reserve in Ukraine

Simoni M., Jo" Rg G, Wolfgang Hr, Axel K., Thorsten K, Daniel S, And Eberhard N., 1999. Journal of Clinical Endocrinology and Metabolism. Vol. 84, No. 2. Institute of Reproductive Medicine of the University (M.S., J.G., A.K., T.K., D.S., E.N.), D-48129. Münster; and Institute of Hormone and Fertility Research, University of Hamburg (W.H.), D-22529 Hamburg, Germany 